\title{
Analisis Sistem Dropship Marketing Perspektif Konsep Maqashid Syariah Al-Syatibi
}

\author{
Riqqa Soviana', Zainal Abidin ${ }^{2}$ \\ IAIN Madura', IAIN Madura ${ }^{2}$ \\ yanay8731@gmail.com¹, zain@iainmadura.ac.id ${ }^{2}$
}

\begin{abstract}
Dropship marketing system is a method of buying and selling online that is intended to achieve ease of transaction between seller and buyer. The benefit to be realized utilizes ecommerce as a practical modern tool. But in practice found a problem in this system that questions the element of mutual benefit between the seller and buyer. The problem is in the form of no need for a seller (dropshipper) to have merchandise to be traded. Whereas the existence of merchandise is a harmony and the conditions that must be met in the practice of buying and selling in order to avoid the element of uncertainty (gharar). Based on that problem then this research was made. This study aims to examine in depth the marketing implementation of the dropship system with the analysis of the concept of maqashid sharia al-Syatibi. The method used is in the form of a literature review with secondary supporting references. The results of this study indicate that the dropship marketing system that has been practiced by the wider community is not in accordance with the concept of maqashid syariah al-Syatibi. This is caused by the existence of lafadz clear orders and prohibitions related to the necessity of having merchandise by the seller, so that between the seller and buyer there is no party who feels disadvantaged. In connection with the most important thing, namely the fulfillment of the elements of maintenance of religion, soul, reason, honor and descent, as well as property as a condition for the achievement of sharia maqashid.
\end{abstract}

Keywords: Dropship Marketing, Maqashid Syariah, Al-Syatibi.

\begin{abstract}
Abstrak
Sistem dropship marketing merupakan metode jual beli online yang dimaksudkan untuk mencapai kemudahan bertransaksi antara penjual dan pembeli. Kemaslahatan yang ingin diwujudkan ini memanfaatkan adanya ecommerce sebagai sarana modern yang praktis. Namun dalam praktiknya ditemukan suatu masalah pada sistem ini yang mempertanyakan kembali unsur kemaslahatan bersama antara penjual dan pembeli. Masalah tersebut berupa tidak perlunya penjual (dropshipper) untuk memiliki barang dagangan yang akan diperniagakan. Padahal keberadaan barang dagangan merupakan rukun dan syarat yang harus dipenuhi dalam praktik jual beli supaya terhindar dari unsur ketidakpastian (gharar). Berdasarkan permasalahan itulah kemudian penelitian ini dibuat. Penelitian ini bertujuan untuk meneliti secara mendalam implementasi pemasaran dari sistem dropship dengan pisau analisa konsep maqashid syariah al-Syatibi. Adapun metode yang digunakan yaitu berupa kajian pustaka dengan referensi-referensi pendukung yang sifatnya sekunder. Hasil dari penelitian ini menunjukkan bahwa sistem dropship marketing yang selama ini dipraktikkan oleh masyarakat luas tidak sesuai dengan konsep maqashid syariah al-Syatibi. Hal ini disebabkan oleh adanya lafadz perintah dan
\end{abstract}


larangan yang jelas terkait keharusan dimilikinya barang dagangan oleh penjual, sehingga antara penjual dan pembeli tidak ada pihak yang merasa dirugikan. Sehubungan dengan hal yang paling penting yaitu terpenuhinya unsur pemeliharaan terhadap agama, jiwa, akal, kehormatan dan keturunan, serta harta sebagai syarat untuk tercapainya maqashid syariah.

Kata kunci: Dropship Marketing, Maqashid Syariah, Al-Syatibi.

\section{PENDAHULUAN}

Menggapai kemashlahatan dan menghindari kerusakan adalah keinginan setiap manusia. Di zaman modern sekarang ini dimana teknologi menjadi sangat canggih, manusia sebagai makhluk ekonomi sangat peka terhadap peluang-peluang di sekitarnya. Segala tindak perbuatan manusia di muka bumi dalam pemenuhan kebutuhan dan pencapaian keinginan membutuhkan adanya alat tukar. Untuk memenuhi kebutuhan dan keinginan tersebut salah satunya dengan cara menukar uang dengan barang yang terwujud dalam akad jual beli.

Adanya kecanggihan teknologi dewasa ini memicu munculnya sistem jual beli yang beragam melalui electronic commerce (e-commerce). Salah satu sistem jual beli yang menarik adalah sistem dropship marketing atau pemasaran secara dropship. Menurut Feri Sulianta, transaksi ini merupakan salah satu metode jual beli secara online dimana badan usaha atau perorangan baik itu toko online atau pengecer (dropshipper) tidak melakukan penyetokan barang. Barang yang akan dijual didapat dari jalinan kerja sama dengan perusahaan lain yang memiliki barang yang sesungguhnya (supplier). Secara istilah, dropshipping adalah metode jual beli secara online, dan supplier adalah perusahaan yang menawarkan barang dagangan untuk dijual yang akan secara langsung mengirim barang kepada konsumen setelah toko online mambayar harga barang dan biaya pengiriman (Rudiana \& Achmad otong Bustomi, 2015: 56).

Dari penjelasan di atas dapat kita pahami bahwa sistem pemasaran ini tergolong unik karena penjual tidak perlu menyetok barang yang akan dijual melainkan langsung meneruskannya kepada supplier. Sehingga, aktivitas jual beli menjadi sangat mudah dan praktis. Akan tetapi dalam sistem dropship ini penjual cenderung tidak mengetahui jumlah stok barang yang tersedia dan tidak memahami betul kualitas barang dan detail informasi sebenarnya. Ketika penjual menerima pertanyaan dari calon pembeli seputar barang ataupun jumlah stok barang, maka penjual masih harus menghubungi supplier. Di tahap ini supplier pun tidak serta merta menerima pertanyaan dari satu penjual saja, melainkan dari beberapa penjual yang mana sama-sama ingin didahulukan mengingat calon pembeli mereka tidak selalu bisa menunggu lama. Kekecewaan ini tidak berakhir di tahap itu saja, melainkan ketika paket mulai dikirim oleh supplier melalui kurir kemudian diterima oleh pembeli, dalam praktiknya 
cenderung menimbulkan kekecewaan pembeli karena ternyata barang yang dibeli tidak sesuai dengan ekspektasi keinginannya. Maka, proses pemenuhan kebutuhan dan pencapaian keinginan pembeli tidak tercapai. Akan tetapi proses pemenuhan kebutuhan dan pencapaian keinginan hanya tercapai pada pihak supplier dan penjual dengan sistem dropship marketing. Sehingga dalam kasus ini, kemashlahatan bersama yang ingin dicapai menjadi rusak atau menjadi mudhorot bagi pihak pembeli.

Sebagai masyarakat muslim, diketahui bahwa masalah jual beli sudah diatur dalam ajaran agama Islam dengan berbagai ketentuan. Dalam fiqh muamalah terkait lingkup ekonomi syariah, rukun jual beli terdiri atas 3 hal. Pertama, pelaku transaksi yaitu penjual dan pembeli. Kedua, objek transaksi yaitu harga dan barang. Ketiga, akad (transaksi) yaitu segala tindakan yang dilakukan kedua belah pihak yang menunjukkan mereka sedang melakukan transaksi, baik tindakan berbentuk kata-kata maupun perbuatan (Mardani, 2012 : 102).

Dari rukun jual beli tadi sudah jelas bahwa dalam hal jual beli sebagai penjual harus memiliki barang yang akan dijualnya terlebih dahulu sebelum menawarkan dan menjualnya kepada pembeli. Jika penjual memiliki barang yang akan dijualnya, maka tentu lebih memahami spesifikasi informasi tentang barang yang akan dijual dari pada penjual yang tidak memiliki barang tersebut. Sehingga, penjual dapat memberikan informasi yang tepat kepada pembeli. Dengan demikian, penjual dapat meminimalisir resiko dalam transaksi jual belinya.

Ketentuan-ketentuan terkait jual beli tersebut merujuk pada aspek maqashid al-syariah. Maqashid al-syariah terdiri dari dua kata, yaitu maqashid dan al-syariah yang mana hubungan antara satu dan lainnya dalam bentuk mudhaf dan mudhaf ilaih. Kata maqashid adalah jamak dari kata maqshad yang artinya adalah maksud dan tujuan. Kata syariah berarti hukum Allah, baik yang ditetapkan sendiri oleh Allah, maupun ditetapkan Nabi sebagai penjelasan atas hukum yang ditetapkan Allah atau dihasilkan oleh mujtahid berdasarkan apa yang ditetapkan oleh Allah atau dijelaskan oleh Nabi. Karena yang dihubungkan kepada kata syariat itu adalah kata "maksud", maka kata syariah berarti pembuat hukum atau syari', bukan hukum itu sendiri. Dengan demikian, kata maqashid al-syariah berarti apa yang dimaksud oleh Allah dalam menetapkan hukum, apa yang dituju Allah dalam menetapkan hukum atau apa yang ingin dicapai Allah dalam menetapkan suatu hukum (Amir Syarifuddin, 2008: 231)

Selanjutnya jika merujuk pengertian maqashid syariah pada Ahmad al-Raysuni, yang mana merupakan salah satu pakar maqashid syariah, (Ika Yunia Fauzia, Abdul Kadir Riyadi, 2014:43). yaitu:

$$
\text { الغايات التى وضغت الشريعة لأجل تحقيقها لمصلحة العباد }
$$


Yang artinya, "Maqashid syariah merupakan tujuan-tujuan yang telah ditetapkan oleh syariah untuk dicapai demi kemashlahatan manusia."

Dengan memahami maksud dari maqashid syariah ini yang berati juga memahami maksud Allah dalam menetapkan suatu hukum, maka dapat kita pahami bahwa kemaslahatan bersama di dunia dan di akhirat adalah tujuan-Nya. Al-mashlahah mencakup segala sesuatu yang bermanfaat, baik secara individual, sosial, maupun alam sekitar. Maka term maslahat dalam penelitian ini lebih diarahkan kepada kemaslahatan sosial atau kemaslahatan bersama. Sebab, kemaslahatan individu tidak selalu berbanding lurus dengan kemaslahatan umum, maka prioritas kemaslahatan bersama menjadi lebih utama (Kementerian Agama, 2012: 178-179).

Menurut Al-Syatibi, sesungguhnya syariah bertujuan untuk mewujudkan kemaslahatan manusia sebagai hamba Allah di dunia dan akhirat. Maka ketika Allah membebankan suatu kewajiban pada hambanya, tak lain yaitu untuk merealisasikan kemaslahatan. Dalam almuwafaqat, salah satu karya besar al-Syatibi, kemaslahatan menjadi inti dari maqashid syariah dapat dilihat dari dua sudut pandang, yaitu:

1. Maqashid al-syari (tujuan Tuhan)

2. Maqashid al-mukallaf (tujuan hamba-Nya)

Untuk memperjelas konsep tersebut, al-syatibi membaginya menjadi 4 poin. Pertama, tujuan awal syariah adalah untuk kemaslahatan manusia di dunia dan di akhirat. Kedua, syariáh sebagai sesuatu yang harus betulbetul dipahami. Ketiga, syariah sebagai hukum taklif (pembebanan) yang harus dikerjakan. Keempat, tujuan syariah yaitu membawa manusia di bawah naungan hukum (Ika Yunia Fauzia, Abdul Kadir Riyadi, 2014: 88).

Maka dari itu dalam penelitian ini akan diteliti secara mendalam tentang implementasi pemasaran yang menggunakan sistem dropship untuk kemudian dianalisis menggunakan konsep maqashid syariah alsyatibi. Sehingga di akhir penelitian nantinya akan ditemukan apakah sistem dropship marketing yang telah dipraktikkan masyarakat luas selama ini telah sesuai atau tidak dengan konsep maqashid syariah yang dikemukakan oleh Al-Syatibi.

\section{KAJIAN LITERATUR}

\section{Sistem Dropship Marketing}

Dropship marketing merupakan teknik manajemen rantai pasokan yang mana penjual (yang berperan sebagai dropshipper atau perantara) tidak memiliki stok barang, melainkan pihak produsenlah (supplier) yang mengirim langsung pada pembeli (Risvan Hadi, 2019: 12). 
Maka model kerjasama antara dropshipper dan supplier secara umum yaitu; pertama, supplier memberikan harga kepada dropshipper yang kemudian dijual kepada konsumen dengan harga yang ditetapkannya sendiri (dengan menambah harga untuk keuntungan dropshipper pribadi); kedua, harga telah ditetapkan oleh supplier sejak awal termasuk fee untuk dropshipper, sehingga dropshipper tidak perlu menambah harga lagi (Muflihatul Bariroh, 2016: 6).

Dengan sistem dropship marketing ini, dropshipper berperan sebagai perantara antara supplier dan konsumen, tanpa harus menyetok barang dagangan yang akan dijual. Dropshipper hanya perlu melakukan promosi terhadap barang yang dijual dengan mencantumkan spesifikasi barang baik material, ukuran, timbangan, dan harga yang akurat. Dalam hal promosi pada umumnya menggunakan sarana berupa gambar atau brosur produk secara keseluruhan, sehingga calon pembeli dapat mengira-ngira wujud asli produk tersebut, baik dari sisi materialnya ataupun kesamaan warna dengan produk aslinya.

\section{Konsep Maqashid Syariah Al-Syatibi}

Kata maqashid syariah berarti apa yang dimaksud dan dituju oleh Allah dalam menetapkan hukum, atau apa yang ingin dicapai Allah dalam menetapkan suatu hukum (Amir Syarifuddin, 2008:231).

Menurut al-Syatibi, syariah bertujuan untuk mewujudkan kemaslahatan manusia sebagai hamba Allah di dunia dan di akhirat. Maka ketika Allah membebankan suatu kewajiban pada hambanya, tak lain yaitu untuk merealisasikan kemaslahatan. Dalam al-muwafaqat, kitab karya al-Syatibi yang masyhur, kemaslahatan menjadi inti dari maqashid syariah dapat dilihat dari sudut pandang maqashid al-Syarí (tujuan Tuhan sebagai membuat hukum) dan maqashid al-mukallaf (tujuan hamba-Nya). Dalam hal ini Al-Syatibi membaginya menjadi 4 poin, di antaranya (Ika Yunia Fauzia, Abdul Kadir Riyadi, 2014:88) :

1. Tujuan awal syariah berkaitan dengan hakikat dari maqashid syariah itu sendiri, yaitu untuk kemaslahatan manusia di dunia dan di akhirat.

2. Syariáh sebagai sesuatu yang harus dipahami melalui maslahat yang terkandung di dalamnya.

3. Syariah sebagai hukum taklif (pembebanan) yang harus dikerjakan dalam rangka mewujudkan kemaslahatan.

4. Tujuan syariah yaitu membawa manusia di bawah naungan hukum. Ini berkaitan dengan kepatuhan manusia sebagai mukallaf terhadap hukum-hukum Allah, yaitu membebaskan manusia dari kekangan hawa nafsu.

Syatibi berpendapat bahwa kemaslahatan dapat terwujud apabila terpeliharanya lima unsur, yaitu unsur agama, jiwa, akal, keturunan, dan 
harta. Kelima unsur tersebut terbagi dalam tiga tingkatan, di antaranya (Ika Yunia Fauzia, Abdul Kadir Riyadi, 2014:89-90)

1. Maqashid al-dlaruriyat, dimaksudkan sebagai pemelihara kelima unsur.

2. Maqashid al-hajiyat, dimaksudkan untuk menghilangkan kesulitan dalam pemeliharaan kelima unsur.

3. Maqashid al-tahsiniyat, dimaksudkan supaya manusia dapat melakukan yang terbaik dalam pemeliharaan kelima unsur.

Adapun cara Syatibi dalam memahami maqashid syariáh yaitu dengan menganalisis lafadz perintah dan larangan yang terdapat dalam Al-Qurán dan Hadits, menganalisis illah yang terdapat dalam perintah dan larangan melalui hukum yang tertulis dan tidak tertulis, serta menganalisis sikap diam Tuhan atau al-sukut án syaríyyati al-a'mal yang berarti tidak ada dalam hukum namun dapat memberikan kemaslahatan dan menghindarkan dari kerusakan (Ika Yunia Fauzia, Abdul Kadir Riyadi :90).

\section{METODE PENELITIAN}

Metodologi yang digunakan dalam penelitian ini berupa kajian pustaka dengan menggunakan berbagai referensi yang berkaitan dengan tema permasalahan, termasuk di dalamnya referensi-referensi pendukung yang sifatnya sekunder. Dalam penelitian ini juga akan dianalisis tentang sistem dropship marketing menggunakan konsep maqashid syariah alsyatibi.

\section{PEMBAHASAN}

\section{Sistem Dropship Marketing}

Dalam Cambridge Business English Dictionary, makna dropshipping adalah pengaturan di mana produsen mengirimkan produk langsung kepada pembeli atas permintaan bisnis yang mengiklankan dan menjual produk akan tetapi tidak memiliki stok atas barang tersebut (Andi Triyawan dan Suthorik Edi Nugroho, 2018: 3).

Menurut Feri Sulianta, transaksi dalam sistem pemasaran dropship merupakan salah satu metode jual beli secara online dimana badan usaha atau perorangan baik itu toko online atau pengecer (dropshipper) tidak melakukan penyetokan barang. Barang yang akan dijual didapat dari jalinan kerja sama dengan perusahaan lain yang memiliki barang yang sesungguhnya atau supplier. Secara istilah, dropshipping adalah metode jual beli secara online, dan supplier adalah perusahaan yang menawarkan barang dagangan untuk dijual yang akan mengirim barang langsung kepada konsumen setelah toko online mambayar harga barang dan biaya pengiriman (Rudiana \& Achmad otong Bustomi, 2015: 56). 
Maka di sini dropshipping merupakan sistem penjualan suatu produk tanpa harus memiliki produk apapun yang dijual. Model kerjasama antara dropshipper dan supplier secara umum yaitu; pertama, supplier memberikan harga kepada dropshipper yang kemudian dijual kepada konsumen dengan harga yang ditetapkannya sendiri (dengan menambah harga untuk keuntungan dropshipper pribadi); kedua, harga telah ditetapkan oleh supplier sejak awal termasuk fee untuk dropshipper, sehingga dropshipper tidak perlu menambah harga lagi (Muflihatul Bariroh, 2016:6).

Pada model yang pertama, supplier memberi kebebasan pada dropshipper untuk menentukan harga jualnya sendiri yang kemudian sering berakibat rusaknya harga di pasaran. Sedangkan pada model kedua, harga di pasaran cenderung stabil sebab harga sudah ditentukan oleh supplier termasuk di dalamnya fee untuk dropshipper atas barang yang telah terjual. Dalam sistem dropship terdapat beberapa model dalam menjalankannya, yaitu (Andi Triyawan dan Suthorik Edi Nugroho, 2018: $4)$.

1. Model bagi hasil, yang mana paling umum digunakan berupa pembagian hasil dari penjualan antara supplier dan dropshipper dan biasanya komisi yang didapat dropshipper tidak lebih dari 50\% harga penjualan.

2. Model jaminan, biasanya berupa pembayaran sejumlah uang oleh dropshipper kepada supplier untuk meminimalisir penipuan yang dilakukan dropshipper melalui e-commerce.

3. Model Web Replika, yang mana diberikan oleh supplier kepada dropshipper sebagai media dalam memasarkan produk melalui ecommmerce, yang kemudian dropshipper menerima komisi melalui web tersebut jika terjadi transaksi.

Sistem dropship marketing memiliki prosedur berantai yang menghubungkan antara pihak supplier dan pihak konsumen. Jadi, penjual yang berperan sebagai dropshipper di sini hanyalah seorang perantara, bukan penjual sebenarnya yang memiliki barang dagangan. Prosedur tersebut dapat dilihat pada gambar di bawah ini (Al-Hafid Ibnu Qayyim, dan Eko Kurniawanto, 2018:5). 
Gambar 1. Prosedur Sistem Dropship Marketing

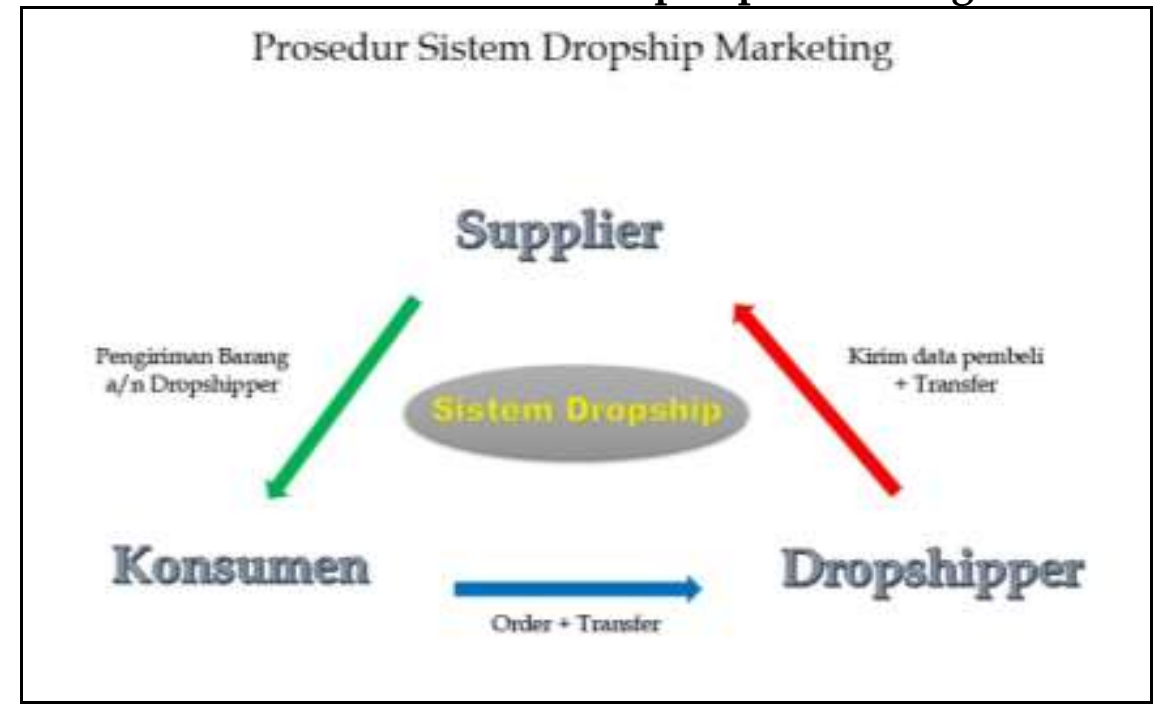

Adapun deskripsinya sebagai berikut:

1. Dropshipper bekerjasama dengan supplier untuk menyepakati sistem jual beli yang akan mereka lakukan.

2. Dropshipper mempromosikan barang yang dijual melalui ecommerce dengan mencantumkan kontak person dropshipper.

3. Konsumen melakukan transaksi dengan dropshipper untuk kemudian membayar harga barang serta ongkos kirim.

4. Dropshipper meneruskan pembayaran konsumen kepada supplier dengan potongan harga sesuai kesepakatan awal.

5. Supplier mengirimkan barang sesuai pesanan kepada konsumen.

Setelah memahami dan memperhatikan runtutan prosedur dalam sistem dropship marketing ini, maka ditemukan beberapa kelebihan dan kekurangan dalam sistem pemasarannya. Di antara beberapa kelebihannya yaitu; pertama, dropshipper memperoleh fee dari hasil penjualan produk tanpa harus memiliki produknya terlebih dahulu; kedua, dropshipper tidak membutuhkan modal besar untuk menjalankan bisnis ini termasuk memiliki kantor ataupun gudang penyimpanan produk; ketiga, dropshipper tidak harus pendidikan tinggi sebab hanya perlu cakap berselancar di dunia maya; keempat, dropshipper tidak perlu mendistribusikan, mengemas, serta mengirim produk kepada konsumen; kelima, dropshipper dapat menjalankan bisnis ini kapanpun dan dimanapun tanpa terbatas ruang dan waktu (Risvan Hadi, 2019:13). Maka tidak heran jika bisnis dengan sistem ini diminati masyarakat luas sebab mampu menciptakan lapangan pekerjaan dengan pangsa pasar yang luas serta berbagai kemudahan dalam menjalankannya. 
Adapun kekurangan dari sistem dropship marketing ini, yaitu; pertama, rendahnya margin yang diterima dropshipper; kedua, masalah dalam hal investasi, tak bisa diandalkan untuk investasi jangka panjang (sebab margin yang rendah); ketiga, kompleksitas dalam pengiriman barang (penyebab biaya membengkak); keempat, kesulitan dalam menjawab komplain konsumen (Andi Triyawan dan Suthorik Edi Nugroho, 2018: 5).

Dalam hal margin yang diperoleh dropshipper biasanya tidak lebih dari $50 \%$ harga penjualan produk. Tentu itu bukan jumlah yang besar, karena itulah seorang dropshipper harus cakap dalam memasarkan produknya sehingga diperoleh keuntungan yang lebih besar dari total akumulasi penjualan yang tidak sedikit. Semakin banyak produk yang terjual, maka akan semakin besar pula total akumulasi penjualan yang diperoleh. Selain itu, memilih produsen yang tepat dapat meningkatkan margin dropshipper, misalnya dengan memilih produsen tangan pertama.

Permasalahan dalam hal kompleksitas pengiriman barang juga sering terjadi. Ketika konsumen membeli beberapa produk yang ditawarkan oleh dropshipper yang mana produk-produk tersebut berasal dari beberapa supplier yang berbeda, maka konsumen harus membayar tiap-tiap biaya pengiriman yang berbeda itu pula. Hal ini menyebabkan biaya yang ditanggung konsumen menjadi membengkak. Sehingga, akan banyak konsumen yang pada akhirnya membatalkan pembelian tersebut. Misalnya, si A membeli beberapa produk kepada si B (sebagai dropshipper yang bekerjasama dengan perusahaan 01, perusahaan 02, dan perusahaan 03). Si A membeli baju perusahaan 01 seharga Rp 150.000 dengan biaya pengiriman Rp 20.000, lalu membeli jilbab perusahaan 02 seharga Rp 80.000 dengan biaya pengiriman Rp 15.000, dan membeli swarovsky brooch perusahaan 03 seharga Rp 250.000 dengan biaya pengiriman $\mathrm{Rp}$ 30.000. Dari total pembelian si A sejumlah Rp 480.000 masih harus membayar biaya pengiriman sejumlah Rp 65.000 sebab adanya pembelian pada supplier yang berbeda. Sehingga total yang harus dibayar si A menjadi Rp 545.000. Lain halnya jika semua produk yang dibeli si A berasal dari satu perusahaan saja, sehingga hanya perlu membayar biaya pengiriman sejumlah Rp 20.000. Maka, total yang harus dibayar si A hanya Rp 500.000 saja.

Permasalahan yang sering terjadi juga yaitu kesulitan dropshipper dalam menjawab komplain konsumen. Biasanya konsumen mengajukan komplain terkait ketidakpuasannya atas barang yang telah dibeli karena tidak sesuai dengan ekspektasi keinginannya ketika melihat promosi yang ditawarkan dropshipper. Sebenarnya hal ini merupakan peristiwa yang wajar sebab dropshipper hanyalah penjual perantara yang tidak memiliki barang dagangan termaksud, melainkan hanya memiliki detail informasi yang dianggap valid terkait produk yang dijual. Namun, melihat 
karakteristik sistem dropship ini tentu tetap dirasa sulit bagi dropshipper untuk menguasai detail produk yang dijual, sebab dropshipper sendiri tidak memilikinya. Termasuk juga ketika konsumen sudah transfer sejumlah uang namun ternyata stok barang di supplier sudah habis terjual. Permasalahan-permasalahan yang rumit ini menyebabkan konsumen kecewa, bahkan penyelesaiannya dapat berujung pada jalur hukum jika permasalahan menjadi sangat rumit.

Beberapa permasalahan yang timbul sebagai akibat dari kekurangan sistem dropship marketing inilah kemudian muncul pertanyaan apakah sistem dropship marketing yang telah dipraktikkan selama ini sesuai atau tidak dengan konsep maqashid syariah yang dikemukakan oleh AlSyatibi.

\section{Konsep Maqashid Syariah Al-Syatibi}

Al-Syatibi memiliki nama lengkap Abu Ishaq Ibrahim Ibn Musa Ibn Muhammad al-Lakhmi al-Gharnati al-Maliki. Ia lahir pada tahun 585 Hijriah di Xativa, yaitu suatu daerah di Spanyol. Nama Syatibi disandarkan pada Shatibah (Xativa) daerah kelahirannya (Ika Yunia Fauzia, Abdul Kadir Riyadi, 2014: 86-87).

Ia kemudian tumbuh besar di Granada (Gharnathah), yaitu Ibu kota kerajaan Nasri yang dipimpin oleh Sultan Muhammad V al-Ghani Bilah, seorang pemimpin di masa kejayaan Granada. Granada juga pada saat itu menjadi pusat keilmuan sehingga banyak dari orang Afrika Utara yang berbondong-bondong menuntut ilmu di sana

Al-Syatibi mempelajari Bahasa Arab dan Nahwu sebagai pendidikan pertamanya, yang diajarkan oleh Abu Abdullah Muhammad Al-Biri. Beliau adalah seorang ahli Nahwu yang terkenal di Andalus. Setelah AlBiri wafat pada tahun 754 Hijriah, Al-Syatibi melanjutkan belajar Bahasa Arab dan Nahwu kepada Abul Qasim al-Sharif al-Sibti. Beliau memiliki julukan "pemegang standar retorika" dan julukan "rais al-ulum allisaniyah" atau raja linguistik. Al-Syatibi belajar kepadanya hingga beliau wafat pada tahun 760 Hijriah.

Al-Syatibi melanjutkan pendidikannya dengan mempelajari Fiqih kepada Abu Saíd bin Lubb di Granada. Beliau adalah seorang mufti dan khatib. Selain itu, Syatibi juga belajar pada guru-guru lainnya seperti Abu Abdullah al-Maqarri, Abu Jaefar al-Syaqwari, Abu al-Abbas al-Qubab, Abu Abdullah al-Hufaz, dan sebagainya. Dari semua guru itu, Abu Abdullah al-Maqarri merupakan yang paling berpengaruh terhadap keilmuan Syatibi. Beliau adalah seorang qadhi di Fez, yang mana beliau kemudian diutus ke Granada untuk menjadi diplomat oleh Sultan Abu Inan. Beliau juga seorang penulis buku Nahwu yang bergelar "muhaqqiq" atau sangat ahli dalam madzhab Maliki di bidang Fiqih. Selain itu beliau juga menulis buku tasawwuf dan ushul Fiqh. Beliau juga seorang Ulama 
yang membawa Syatibi ke dalam dunia Sufi. Selain mempelajari ilmuilmu tadi, Syatibi juga mempelajari ilmu rasional (úlum al-áqliyah) kepada Abu Ali Mansur al-Zawawi dan Abu Abdullah al-Sharif al-Tilmisani yang mana keduanya adalah seorang ilmuwan besar di Granada. Keduanya juga merupakan ulama' yang berpengaruh dalam bidang filosofi dan teologi.

Selain menjadi murid, Syatibi juga menjadi guru bagi beberapa muridnya yaitu Abu Yahya bin Asim, Abu Bakar bin Asim, dan Abu Abdullah al-Bayani (Nabila Zatadini dan Syamsuri, 2019: 3).

Adapun karya-karya al-Syatibi mengacu pada Ulum al-Wasilah yang merupakan jalan untuk memahami Ulum al-Maqashid, di antaranya (Abdurrahman Kasdi, 2014: 6-7):

1. Kitab al-Muwafaqat. Kitab ini merupakan karya besar yang paling terkenal di antara kitab-kitab karya al-Syatibi lainnya. Awalnya kitab ini berjudul al-Ta'rif bi Asrar al-Taklif, namun setelah al-Syatibi bermimpi maka diubahlah judul kitab ini menjadi al-Muwafaqat. Kitab ini berisi tentang pembaharuan dalam memahami syariáh dengan cara membawa akal untuk memahami maqashid dan rahasia-rahasia yang terkandung di dalamnya yang terdiri atas 4 juz.

2. Kitab al-I'tisham. Kitab ini ditulis setelah menulis kitab alMuwafaqat. Kitab ini membahas tentang bidáh dan seluk beluknya secara panjang lebar, yang terdiri atas 2 juz. Namun beliau wafat sebelum merampungkan kitab ini.

3. Kitab al-Majalis. Kitab ini merupakan syarah dari kitab al-buyu' pada Shahih Bukhari.

4. Syarah al-Khulashah. Kitab ini adalah kitab Nahwu yang merupakan syarah dari kitab Alfiyyah Ibn Malik. Kitab ini terdiri atas 4 juz.

5. Unwan al-Ittifaq fi 'Ilm al-Isytiqaq. Kitab ini merupakan kitab tentang Ilmu Sharraf dan Fiqh Lughah. Namun buku ini telah hilang saat al-Syatibi masih hidup.

6. Ushul an-Nahw. Kitab ini membahas tentang Qawaid Lughah dalam Ilmu Sharraf dan Nahwu, serta membahas juga tentang Qawaid Ashliyah. Namun buku ini juga telah hilang saat al-Syatibi masih hidup.

7. Al-Ifadat wa al-Insyadat. Kitab ini berisi gambaran perjalanan hidup al-Syatibi, termasuk di dalamnya tentang para guru dan muridmuridnya.

8. Fatawa Asy-Syathibi. Kitab ini berisi tentang kumpulan fatwa yang tersebar dalam kitab al-I'tisham dan al-muwafaqat.

Pemikiran-pemikiran al-Syatibi mendapat respon positif dari berbagai kalangan Muslim dari berbagai generasi juga oleh sebab kepakarannya yang unggul dari pada ulama-ulama di zamannya. Banyak 
dari para ulama yang memberikan appresiasi terhadap karya-karya alSyatibi. Seperti Abu Wasim bin Siraj, seorang ulama Spanyol mengaku bahwa ia sulit untuk berfatwa dengan fatwa-fatwa yang berbeda dengan apa yang difatwakan al-Syatibi. Kemudian menurut Abu Abdullah alMajari al-Andalusi, al-Syatibi adalah maha guru yang terkenal di zamannya. Lalu menurut Muhammad Rasyid Rida, karya-karya al-Syatibi memiliki orisinalitas pemikiran hukum yang bobot dan monumentalnya dapat disejajarkan dengan karya Ibnu Khaldun yang berjudul alMuqaddimah. Selain ketiga ulama tadi, ada pula apresiasi dari seorang tokoh penting pembaharu Islam yaitu Muhammad Abduh. Beliau berkesimpulan bahwa al-Muwafaqat merupakan mata rantai yang penting bagi pengembangan pemikiran hukum dalam Islam. Oleh karena itu, Muhammad Abduh menganjurkan kepada generasi yang akan datang untuk menelaáh al-Muwafaqat dan menjadikannya rujukan penting dalam pengembangan aspek falsafah hukum Islam

Dalam kitab al-Muwafaqat terdapat pemikiran al-Syatibi bahwasanya inti dari maqashid syariáh adalah kemaslahatan. Secara etimologis, kata maslahah memiliki arti manfaat, yaitu faedah, bagus, baik (kebaikan), dan guna (kegunaan). Dalam kamus besar Bahasa Indonesia, kata maslahat diartikan dengan sesuatu yang mendatangkan kebaikan, bermanfaat, dan berguna. Sedangkan kemaslahatan bermakna kegunaan, kebaikan, manfaat, dan kepentingan.

Kemaslahatan dalam maqashid syariah ini dapat dilihat dari sudut pandang maqashid al-syarí (tujuan Tuhan) dan maqashid al-mukallaf (tujuan hamba-Nya). Sebagaimana dalam kitab al-Muwafaqat:

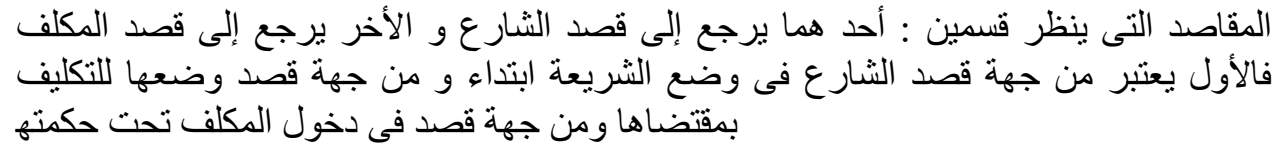

Maqashid terbagi menjadi dua sudut pandang, yaitu; pertama, kembali pada tujuan Syari'(pembuat hukum); dan kedua, kembali pada tujuan mukallaf. Pada sudut pandang maqashid syarí berkaitan dengan tujuan Tuhan dalam menetapkan prinsip ajaran syariát, yang mana tujuan-Nya supaya dipahami dan dilaksanakan oleh manusia yang dibebani oleh syariát. Sedangkan pada sudut pandang maqashid almukallaf yaitu supaya manusia memahami esensi dari hikmah syariát tersebut (Abdurrahman Kasdi, 2014: 6-7).

Dalam hal ini Al-Syatibi membaginya menjadi 4 poin, di antaranya:

Tujuan awal syariah berkaitan dengan hakikat dari maqashid syariah itu sendiri, yaitu untuk kemaslahatan manusia di dunia dan akhirat.

1. Syariáh sebagai sesuatu yang harus dipahami melalui maslahat yang terkandung di dalamnya. 
2. Syariah sebagai hukum taklif (pembebanan) yang harus dikerjakan dalam rangka mewujudkan kemaslahatan.

3. Tujuan syariah yaitu membawa manusia di bawah naungan hukum. Ini berkaitan dengan kepatuhan manusia sebagai mukallaf terhadap hukum-hukum Allah, yaitu membebaskan manusia dari kekangan hawa nafsu.

Adapun maqashid syariáh dalam Al-Qurán dan As-Sunnah telah disebutkan secara langsung bahwasanya maqashid syariáh ditujukan untuk urgensi pemenuhan kemaslahatan bagi seluruh manusia dan untuk menyelamatkan mereka dari bahaya, atau yang sering disebut dengan jalbul mashalih wa darúl mafasid (Nabila Zatadini dan Syamsuri, 2019: 5).

Syatibi berpendapat bahwa kemaslahatan dapat diwujudkan jika dapat memelihara lima unsur, yaitu unsur agama, jiwa, akal, kehormatan dan keturunan, serta harta. Kelima unsur tersebut terbagi dalam tiga tingkatan, di antaranya (Ika Yunia Fauzia, Abdul Kadir Riyadi, 2014: 8990).

1. Maqashid al-dlaruriyat (Galuh Nashrullah, Kartika Mayangsari R, dan H. Hasni Noor, 2014: 5-6).

Kebutuhan akan dlaruriyat ini merupakan kebutuhan yang harus ada, sebab tanpa terpenuhinya kebutuhan dlaruriyat ini dapat menyebabkan terancamnya kehidupan manusia di dunia maupun di akhirat. Kebutuhan dlaruriyat juga disebut sebagai kebutuhan primer. Kebutuhan ini dimaksudkan untuk memelihara kelima unsur yaitu memelihara agama, memelihara jiwa, memelihara akal, memelihara kehormatan dan keturunan, serta memelihara harta. Untuk maksud itulah syariat Islam diturunkan. Begitu juga jika meneliti setiap ayat hukum maka akan ditemukan alasan pembentukannya. Misalnya dalam firman Allah tentang kewajiban jihad dalam surat AL-Baqarah ayat 193, yaitu:

$$
\text { وقاتلو هم حتى لا تكون فتنة ويكون الدين لله فإن انتهوا فلا عدوان إلا على الظالمين }
$$

Artinya, "Dan perangilah mereka itu, sehingga tidak ada fitnah lagi dan (sehingga) ketaatan itu Hanya semata-mata untuk Allah. jika mereka berhenti (dari memusuhi kamu), Maka tidak ada permusuhan (lagi), kecuali terhadap orang-orang yang zalim."

Dari ayat di atas dapat diketahui bahwa disyariatkannya berperang bertujuan untuk kelancaran proses dakwah bila terjadi gangguan dalam mengajak manusia untuk menyembah Allah.

Contoh lain, yaitu firman Allah tentang qishash dalam surat AlBaqarah ayat 179 , yaitu:

$$
\text { ولكم فى القصاص حباة يا أولى الألباب لعلكم تتقون }
$$


Artinya, "Dan dalam qishash itu ada (jaminan kelangsungan) hidup bagimu, Hai orang-orang yang bertakwa."

Dari ayat tersebut dapat diketahui bahwa tujuan disyariatkannya qishash yakni untuk menghilangkan ancaman terhadap kehidupan manusia di muka bumi. Jadi, adanya hukum qishash dimaksudkan untuk melestarikan kehidupan manusia sebab jeranya pelaku criminal sehingga kehidupan pun menjadi aman dan sejahtera.

1) Maqashid al-hajiyat

Kebutuhan hajiyat merupakan kebutuhan yang dimaksudkan untuk menghilangkan kesulitan dalam pemeliharaan kelima unsur. Tidak terpenuhinya kebutuhan ini tidak mengancam keselamatan namun akan mengalami kesulitan. Keberadaan syariat Islam inilah yang dapat menghilangkan segala bentuk kesulitan tersebut. Seperti adanya rukhshah atau dispensasi dalam hal ibadah. Sebagai contoh, diperbolehkannya meng-qashar shalat, diperbolehkannya tidak berpuasa dalam perjalanan dengan jarak tertentu, dan sebagainya. Contoh lain dalam hal ekonomi syariah, diperbolehkannya melakukan akad mudharabah, muzaraáh, musaqat, dan bai'as-salam, serta aktivitas ekonomi lainnya dengan tujuan kemudahan dalam hidup dan menghilangkan kesulitan

2) Maqashid al-tahsiniyat.

Kebutuhan tahsiniyat ini dimaksudkan supaya manusia dapat melakukan yang terbaik dalam pemeliharaan kelima unsur. Kebutuhan ini merupakan kebutuhan pelengkap, yang mana jika tidak terpenuhinya kebutuhan ini maka tidak akan menimbulkan kesulitan dan tidak mengancam eksistensi dari unsur agama, jiwa, akal, kehormatan dan keturunan, serta harta. Adanya kebutuhan tahsiniyat ini yakni untuk dilakukan secara patut menurut adat istiadat yang sesuai dengan tuntutan moral dan akhlak. Misalnya kesopanan dalam bertutur dan bertindak, serta pengembangan kualitas produksi dan hasil kerja. Kebutuhan ini juga penting dalam menyempurnakan kebutuhan-kebutuhan lainnya, sebab kebutuhan tahsiniyat ini memperhatikan masalah etika dan estetika seperti kebersihan, berhias, shadaqah, dan sebagainya. Contoh dalam ibadah yaitu anjuran memperbanyak Ibadah sunnah (Galuh Nashrullah, Kartika Mayangsari R, dan H. Hasni Noor, 2014: 6).

Adapun cara Syatibi dalam memahami maqashid syariáh yaitu dengan menganalisis lafadz perintah dan larangan yang ada, menganalisis illah yang terdapat dalam perintah dan larangan, serta menganalisis sikap diam Tuhan atau al-sukut án syaríyyati al- 
a'mal. Pada cara yang pertama yakni menganalisis lafadz perintah dan larangan di dalam Al-Qurán dan Hadits sebelum dikaitkan dengan permasalahan lain. Pada cara yang kedua, menganalisis illah yang tertulis (yang tampak) atau tidak. Menurut Syatibi illah yang tertulis harus diikuti, sebab hal tersebut menjadi tujuan hukum yang harus dicapai. Misalnya dalam hal jual beli merupakan aktivitas yang bertujuan untuk saling memberi manfaat. Adapun illah yang tidak tertulis (tidak tampak) maka permasalahannya dikembalikan pada Allah (sebagai syari') atau diberhentikan (tawaqquf). Tawaqquf yang ditawarkan Syatibi ini dimaksudkan untuk kehati-hatian sebab adanya pertimbangan atas dua sisi, yaitu sisi yang melarang perluasan terhadap cakupan nash (perluasan tanpa illah hukum) dan sisi yang membuka kemungkinan perluasan cakupan nash (jika tujuan hukumnya diketahui). Selanjutnya cara yang ketiga, menganalisis sikap diam Syari' yang tidak diarahkan kepada hukum-hukum yang tidak disebutkan namun memberikan kemaslahatan dan menghindarkan kerusakan bagi manusia (Ika Yunia Fauzia, Abdul Kadir Riyadi, 2014: 90-91).

Maka dari itu, konsep maqashid syariáh al-Syatibi inilah yang kemudian peneliti gunakan sebagai pisau analisa terhadap sistem dropship marketing dalam penelitian kepustakaan ini. Sehingga di akhir penelitian nantinya akan ditemukan apakah sistem dropship marketing yang telah dipraktikkan masyarakat luas selama ini sesuai atau tidak dengan konsep maqashid syariah yang dikemukakan oleh Al-Syatibi.

\section{Analisis Sistem Dropship Marketing Perspektif Konsep Maqashid Syariah Al-Syatibi}

Bertolak dari permasalahan yang ada, sistem dropship marketing sebenarnya merupakan metode jual beli online yang dimaksudkan untuk mencapai kemudahan bertransaksi antara penjual dan pembeli dewasa ini. Kemaslahatan yang ingin diwujudkan oleh sistem ini berawal dari munculnya electronic commerce (e-commerce) sebagai sarana modern yang praktis dalam memudahkan urusan-urusan masyarakat. Sistem dropship marketing juga muncul sebagai solusi untuk mencapai kemudahan pemasaran bagi perusahaan-perusahaan untuk menjangkau konsumen yang lebih luas. Proses pelebaran sayap bagi perusahaan merupakan hal yang sangat penting demi keberlangsungan hidup suatu perusahaan. Hal tersebut juga dimaksudkan supaya suatu perusahaan dapat senantiasa bertahan dalam segala bentuk pandemi. Namun dalam praktiknya ditemukan permasalahan pada sistem dropship ini sehubungan dengan unsur kemaslahatan bersama antara penjual dan 
pembeli. Maka dari itulah term maslahat dalam penelitian ini lebih dicondongkan pada kemaslahatan sosial. Sebab, kemaslahatan individu tidak selalu berbanding lurus dengan kemaslahatan umum yang semestinya lebih diprioritaskan.

Dalam penelitian ini peneliti menemukan suatu permasalahan terkait praktik jual beli dengan sistem dropship marketing, yaitu tidak adanya barang dagangan pada penjual (dropshipper) bahkan tidak dibutuhkannya dropshipper untuk memiliki barang dagangan. Jual beli yang hakikatnya pertukaran sesuatu dengan sesuatu yang lain menjadi terganggu oleh sebab keberadaan permasalahan tadi, sehingga maqashid dari hukum jual beli itu sendiri tidak tercapai. Untuk mencapai maqashid syariah termaksud dalam jual beli maka sangat perlu untuk mengoreksi kembali sistem dropship ini dengan analisis maqashid syariah perspektif al-Syatibi.

Menurut al-Syatibi, inti dari maqashid syariah adalah kemaslahatan. Kemashlahatan di sini dapat diukur dari besarnya kemanfaatan, kebaikan, dan kegunaan di dalamnya. Maqashid syariah ini pun akan terwujud jika unsur pemeliharaan terhadap agama, jiwa, akal, kehormatan dan keturunan, serta harta terpenuhi. Untuk itu penting bagi manusia memahami betul maqashid dari disyariatkannya hukum jual beli serta sepenuhnya patuh pada hukum syarí supaya tercapai apa yang dinamakan dengan kemaslahatan bersama.

Sehubungan dengan permasalahan yang ada yaitu tidak adanya barang dagangan pada penjual (dropshipper). Keberadaan barang dagangan pada penjual menjadi salah satu rukun dan syarat sahnya jual beli, yang berarti barang dagangan harus dimiliki terlebih dahulu oleh penjual. Di antara beberapa rukun jual beli menurut jumhur ulama yaitu bai' (penjual), musytari (pembeli), sighat (ijab dan qabul), dan ma'qud alaih (objek akad atau barang dagangan). Sedangkan syarat sahnya jual beli terkait objek akad yaitu (Rachmat Syafeí, 2001:76-78) :

Pertama, objek akad harus ada. Tidak boleh berakad atas barang yang tidak ada seperti jual beli buah yang belum nampak, jual beli anak hewan yang masih dalam kandungan induknya, jual beli burung di udara, dan jual beli ikan yang masih ada di dalam laut. Kedua, objek akad harus kuat, tetap, bernilai, dapat dimanfaatkan dan disimpan. Ketiga, objek akad harus milik sendiri. Keempat, objek akad dapat diserahkan.

Begitu juga dalam kitab al-Tadzhib fi adillati matan al-ghaayat wa alTaqrib, dinyatakan bahwa jual beli akan sah jika barang dagangan telah dimiliki oleh penjual. Jika barang dagangan belum dimiliki, maka jual beli menjadi tidak sah. Sebagaimana sabda Rasulullah saw (Mushthafa Dib alBagha, Al-Tadzhib : 123):

$$
\text { ولا بيع إلا فيما تملك }
$$


Artinya, "Tidak ada jual beli kecuali (objek akad) telah dimiliki." (HR. Abu Daud).

Dari hadits tersebut diketahui bahwa kepemilikan atas barang dagangan merupakan hal yang sangat vital, sebab berkaitan dengan sah tidaknya praktik jual beli yang dilakukan. Maka dalam permasalahan ini, lafadh perintah kepemilikan barang dagangan oleh penjual sudah jelas, yaitu penjual harus memiliki barang dagangannya terlebih dahulu. Kepemilikan atas barang dagangan ini tidak hanya berlaku untuk penjual sebenarnya (supplier) akan tetapi juga berlaku untuk penjual perantara (dropshipper). Namun penjual tidak lagi disebut sebagai dropshipper jika memiliki barang dagangannya terlebih dahulu, melainkan disebut sebagai reseller, sebab karakteristik dari sistem pemasaran dropship ini yaitu penjual tidak memiliki barang dagangan yang akan dijualnya. Dengan kata lain hanya sebagai perantara antara supplier dan konsumen.

Ketiadaan barang dagangan pada penjual berakibat ketidakpastian (gharar) atas apa yang sedang dijualnya, yang kemudian berakibat juga pada ketidakpastian pembeli atas apa yang ia beli. Ketidakpastian di sini mencakup banyak hal. Misalkan jual beli pakaian dengan sistem dropship yang mana penjual tidak memiliki barang yang dijual. Maka sudah pasti penjual tidak mengetahui detail informasi seluruhnya pada pakaian tersebut, sehingga timbullah ketidakpastian pada ukuran pakaian, akurasi harga, dan material dengan detail grade-nya yang sangat berpengaruh pada minat dan ketertarikan pembeli. Termasuk juga tentang tekstur pakaiannya apakah kasar, berpori, atau lembut. Bagaimana kondisi tubuh saat pakaiannya dipakai, apakah panas atau sejuk dapat menyerap keringat, dan lain sebagainya. Jual beli semacam ini disebut juga jual beli gharar atau jual beli yang tidak pasti bentuk dan wujudnya sehingga sangat wajar jika Rasulullah melarangnya, dalam sabda Beliau saw,

$$
\text { نهى رسول الله صلى الله عليه وسلم عن بيع الغرر }
$$

Artinya, "Rasulullah saw telah melarang jual beli gharar." (HR. Muslim).

Definisi gharar menurut beberapa sarjana klasik yaitu menurut Ibn 'Abidin gharar sebagai syak terhadap kewujudan barang sama ada, didapat atau tidaknya barang yang telah dibeli tersebut. Menurut Ibn Hazam gharar sebagai jahalah yaitu ketidaktahuan terhadap barang yang dijual, pembeli tidak tahu apa yang dibelinya dan penjual juga tidak tahu apa yang dijualnya. Sedangkan Al-Sarakhsi mendefinisikan gharar sebagai apa yang membawa kepada akibat yang tersembunyi dan tidak diketahui (Abdul Hadi bin Awang, 2012: 65-66). 
Dari ketiga definisi tersebut dapat disimpulkan bahwa adanya unsur gharar dalam jual beli dapat menyebabkan kerugian bagi pembeli maupun penjual sendiri.

Disyariatkannya suatu hukum dalam segala aspek kehidupan manusia tidak lain untuk kebaikan manusia itu sendiri, sehingga sudah semestinya dipatuhi dan dipahami maksud serta tujuan hukum tersebut. Dalam permasalahan ini sudah jelas adanya lafadh perintah dan larangan terkait pentingnya keberadaan barang dagangan di tangan penjual dan bahayanya menjual barang dalam ketidakpastian (gharar). Selain merugikan pembeli, juga merugikan penjual itu sendiri. Penjual yang hanya berperan sebagai dropshipper dapat mengalami kesulitan ketika menerima komplain dari konsumen atas ketidaksesuaian barang dagangan yang diterimanya. Sehingga mau tidak mau penjuallah yang harus bertanggungjawab. Termasuk jika kemudian permasalahan menjadi sangat rumit, maka dapat berujung pada jalur hukum. Sehingga, kemaslahatan yang mestinya dapat terwujud melalui praktik jual beli, menjadi tidak terwujud oleh sebab adanya rukun dan syarat jual beli yang tidak terpenuhi.

Kemaslahatan tidak dapat terwujud dengan tidak adanya unsur kebaikan dalam sistem dropship ini. Begitu juga unsur pemeliharaan jiwa, akal, kehormatan, serta harta juga menjadi tidak terpenuhi sebab muncul permasalahan yang tidak diinginkan antara penjual dan pembeli yang membahayakan bagi keduanya. Sehingga menurut Syatibi, hal ini termasuk dalam kebutuhan dlaruriyat, yakni kebutuhan yang harus dilakukan supaya dapat memelihara unsur jiwa, akal, kehormatan, serta harta. Jika tidak, maka akan menyebabkan mudharat atau bahaya. Dalam kaidah fiqih dikatakan bahwa,

$$
\text { درء المفاسد أولى من جلب المنافع }
$$

Artinya, "Menangkal mafsadat adalah lebih utama dari menarik manfaat." (Abbas Arfan, 2012: 51).

Dengan kata lain, sistem dropship marketing ini sebaiknya tidak dilakukan walaupun memiliki beberapa keuntungan dan praktis dalam menjalankannya, tak lain supaya terhindar dari masalah yang mengancam jiwa, akal, kehormatan, serta harta, baik di dunia maupun di akhirat. Sikap kehati-hatian ini jauh lebih baik dari pada berspekulasi dengan jual beli yang tidak pasti.

\section{KESIMPULAN}

Adanya electronic commerce dewasa ini memunculkan berbagai kemudahan dalam menyelesaikan urusan-urusan masyarakat termasuk 
dalam hal jual beli dengan sistem dropship marketing. Sistem jual beli ini sangat mudah dan praktis dalam menjalankannya. Namun dalam sistem ini tidak membutuhkan kepemilikan barang dagangan bagi penjual, sehingga seringkali jual beli yang terjadi menimbulkan ketidakpastian (gharar) atas apa yang dijual dan dibeli. Hal ini bertentangan dengan prinsip Islam yang mana kepemilikan barang dagangan merupakan salah satu rukun dan syarat yang harus dipenuhi oleh penjual. Jika tidak terpenuhi, maka transaksi jual beli menjadi tidak sah. Disyariatkannya hukum jual beli ini juga dalam rangka mencapai kemaslahatan bersama antara penjual dan pembeli, sehingga tidak ada pihak yang merasa dirugikan. Perspektif al-Syatibi terkait permasalahan pada sistem dropship ini yaitu tidak sesuai dengan konsep maqaship syariah. Adanya lafadh perintah dan larangan yang jelas mengharuskan dimilikinya barang dagangan oleh penjual. Menurut al-Syatibi, permasalahan ini termasuk dalam kebutuhan dlaruriyat yang harus terpenuhi. Maka dari itu, sistem dropship marketing sebaiknya tidak dilakukan walaupun memiliki beberapa keuntungan dan praktis dalam menjalankannya tak lain supaya terpeliharanya unsur agama, jiwa, akal, kehormatan dan keturunan, serta harta. Sebagai pebisnis, sudah seharusnyalah untuk lebih mengedepankan sikap kehati-hatian supaya tercapai kemaslahatan bersama.

\section{DAFTAR PUSTAKA}

Abbas Arfan, (2012), Kaidah-Kaidah Fiqih Muamalah dan Aplikasinya Dalam Ekonomi Islam, Malang: UIN Maliki Press.

Abdul Hadi bin Awang, (2012), Gharar Dalam Perspektif Fiqh Al-Hadits: Analisis Terhadap Íllah Dan Prinsip, Jurnal HADIS, Vol: 02, No: 4.

Abdurrahman Kasdi, (2014), Maqashid Syariáh Perspektif Pemikiran Imam Syatibi Dalam Kitab Al-Muwafaqat, Jurnal Yudisia, Vol: 05, No: 4.

Al-Hafid Ibnu Qayyim, dan Eko Kurniawanto, (2018), Hukum Jual Beli Online Dengan Sistem Dropship Menurut Syariah, Jurnal Ekonomika, Vol: 07, No: 2.

Amir Syarifuddin, (2008), Ushul Figh, Jakarta: Kharisma Putra Utama.

Andi Triyawan dan Suthorik Edi Nugroho, (2018), Sistem Dropshipping Menurut Ekonomi Islam, Jurnal Human Falah, Vol: 05, No: 2.

Ika Yunia Fauzia, Abdul Kadir Riyadi, (2014), Prinsip Dasar Ekonomi Islam Perspektif Maqashid al-Syariah, Jakarta: PT. Fajar Interpratama Mandiri.

Imron Rosyadi, (2013), Pemikiran Asy-Syatibi Tentang Maslahah Mursalah. Jurnal Profetika, Vol: 14, No: 1.

Galuh Nashrullah, Kartika Mayangsari R, dan H. Hasni Noor, (2014), Konsep Maqashid Al-Syariah Dalam Menentukan Hukum Islam 
(Perspektif Al-Syatibi dan Jasser Auda). Jurnal Al-Iqtishadiyah, Vol: 01, No: 1.

Kementerian Agama, (2012), Pembangunan Ekonomi Umat, Jakarta: Lajnah Pentashihan Mushaf Al-Qurán.

Mardani, (2012), Fiqh Ekonomi Syariah, Jakarta: Kencana.

Mushthafa Dib al-Bagha, Al-Tadzhib fi adillati matan al-ghaayat wa al-Taqrib, Malang: UIN Malang Press.

Muflihatul Bariroh, (2016), Transaksi Jual Beli Dropshipping Dalam Perspektif Fiqh Muamalah, Jurnal Ahkam, Vol: 04, No: 2.

Nabila Zatadini dan Syamsuri, (2019), Konsep Maqashid Syariah Menurut

Al-Syatibi dan Kontribusinya Dalam Kebijakan Fiskal, Jurnal Masharifal-Syariáh, Vol: 04, No: 1.

Rachmat Syafeí, (2001), Fiqih Muamalah, Bandung: Pustaka Setia.

Rudiana \& Achmad otong Bustomi, (2015), Transaksi Dropshipping Perspektif Ekonomi Syariah, Jurnal Al-Mustashfa, Vol: 03, No: 1.

Risvan Hadi, (2019), Analisis Praktek Jual Beli Dropshipping Dalam Perspektif Ekonomi Islam. Jurnal At-Tawassuth, Vol: 04, No: 2. 